\title{
Description of Enterovibrio nigricans sp. nov., reclassification of Vibrio calviensis as Enterovibrio calviensis comb. nov. and emended description of the genus Enterovibrio Thompson et al. 2002
}

\author{
Correspondence \\ María J. Pujalte \\ maria.j.pujalte@uv.es
}

\author{
Javier Pascual, ${ }^{1,2}$ M. Carmen Macián, ${ }^{3}$ David R. Arahal, ${ }^{2,3}$ \\ Esperanza Garay ${ }^{2,3}$ and María J. Pujalte ${ }^{1,2}$
}

Eleven strains of halophilic, facultative anaerobes isolated from healthy and diseased Dentex dentex and Sparus aurata (bony fishes) cultured in Spanish Mediterranean fisheries have been studied by a polyphasic approach that included a wide phenotypic characterization, DNA-DNA hybridization and phylogenetic analysis using $16 \mathrm{~S}$ rRNA, recA and rpoD gene sequences. All strains were phylogenetically related to Enterovibrio species and Vibrio calviensis. On the basis of sequence analysis and DNA-DNA hybridization data, eight of the strains were identified as Enterovibrio coralii. The remaining three strains formed a tight, independent clade in all sequence analyses and showed less than $70 \%$ DNA-DNA hybridization with strains of the closest Enterovibrio species, from which they could be differentiated by several phenotypic traits. We conclude that these three strains represent a novel species in the genus Enterovibrio and we thus propose the name Enterovibrio nigricans sp. nov., with strain DAI 1-1-5 ${ }^{\top}\left(=\right.$ CECT $7320^{\top}=$ CAIM $\left.661^{\top}\right)$ as the type strain. In addition, we propose the reclassification of Vibrio calviensis Denner et al. 2002 as Enterovibrio calviensis comb. nov. (type strain RE35/F12 ${ }^{\top}=\mathrm{CIP} 107077^{\top}=\mathrm{DSM}$ $14347^{\top}=$ CECT $7414^{\top}$ ) and we provide an emended description of the genus Enterovibrio.
The genus Enterovibrio was proposed by Thompson et al. (2002) to accommodate a group of isolates obtained from larvae of Scophthalmus maximus, described as the novel species Enterovibrio norvegicus. The strains shared some phenotypic characteristics with Vibrio species but were phylogenetically closer to Grimontia hollisae (basonym Vibrio hollisae), although they shared only $94 \% 16 \mathrm{~S}$ rRNA gene sequence similarity. Three years later, a second Enterovibrio species was described, Enterovibrio coralii, isolated from diseased corals (Thompson et al., 2005b). It

Abbreviations: ML, maximum likelihood; MP, maximum parsimony; $\mathrm{NJ}$, neighbour joining.

The GenBank/EMBL/DDBJ accession numbers for the $r p o D$, rec $A$ and 16S rRNA gene sequences determined in this study are AM942047AM942062, AM942063-AM942078 and AM942722-AM942732, respectively, as detailed in Table 1.

Photographs of colonies of strain DAl $1-1-5^{\top}, \mathrm{ML}$ and MP trees based on $16 S$ rRNA, recA and $r p o D$ gene sequences and a concatenated dataset, growth responses and cellular fatty acid profiles of individual strains and detailed DNA-DNA hybridization results are available as supplementary material with the online version of this paper. is also recognized, although no formal proposal has been made, that Vibrio calviensis (Denner et al., 2002) shares greater phylogenetic relatedness with members of Enterovibrio than with Vibrio species, according to recent phylogenetic analyses (Thompson et al., 2005b; Sawabe et al., 2007). In fact, the generic assignment of V. calviensis was already considered somewhat provisional at the time of its description (Denner et al., 2002).

During two surveys on bacteria associated with the internal organs of the cultured fish Dentex dentex (Company et al., 1999) and Sparus aurata (Pujalte et al., 2003), a group of strains isolated from the head kidney, unidentifiable by phenotyping, were found to be related to E. coralii by comparative analysis of $16 \mathrm{~S}$ rRNA gene sequences. On initial isolation, the strains were considered as nonfermentative, so the taxonomic link with the genus Enterovibrio was surprising, and prompted a deeper characterization that has been performed through a wide phenotypic study, DNA-DNA hybridization and phylogenetic analysis using three housekeeping genes, the $16 \mathrm{~S}$ rRNA gene, $r p o D$ and recA. 
Table 1 shows the origin of the strains and/or sequences included in the study. Wild strains were isolated by direct streaking of a loop from Dentex dentex head kidney on tryptone soy agar (TSA) supplemented with $1 \%(\mathrm{w} / \mathrm{v})$ $\mathrm{NaCl}$, or from Sparus aurata head kidney on marine agar (MA) plates, incubated at room temperature $\left(20-24{ }^{\circ} \mathrm{C}\right)$ for 2-7 days. Isolated strains were maintained as stab cultures in semisolid marine broth [MB, plus $0.2 \%(\mathrm{w} / \mathrm{v})$ agar] and suspended in MB plus $20 \%(\mathrm{w} / \mathrm{v})$ glycerol at $-80{ }^{\circ} \mathrm{C}$ for long-term storage.

Methods for phenotypic characterization have been reported elsewhere (Macián et al., 2001a). Strains E. coralii CAIM $912^{\mathrm{T}}$, E. norvegicus CECT $7288^{\mathrm{T}}$ and V. calviensis DSM $14347^{\mathrm{T}}$ were characterized along with 11 wild strains. All strains were routinely cultivated on MA or in MB and incubated at $20-22{ }^{\circ} \mathrm{C}$.

Wild strains were Gram-negative, motile, oxidase-positive rods and showed, on initial characterization, no ability to ferment glucose anaerobically on Møller's decarboxylase medium plus $2 \%(\mathrm{w} / \mathrm{v}) \mathrm{NaCl}$. Later testing on OF medium plus glucose with half-strength artificial seawater revealed that all of them were able to ferment glucose under anaerobic conditions after $2-3$ days incubation, but acid production was weak within the first $24 \mathrm{~h}$, not allowing a clear identification of the strains as members of the Vibrionaceae. Growth on thiosulfate citrate bile sucrose (TCBS) medium, a selective medium routinely used for vibrio selection, was also slow and poor in most cases, and gave rise to small, green colonies (i.e. not fermenting sucrose). None of the strains was able to hydrolyse gelatin, casein, starch or alginate. The two strains isolated from Sparus aurata produced a black/deep-brown, slightly diffusible pigment that accumulated in isolated colonies and peripheral mass growth after prolonged incubation on MA (Supplementary Fig. S1, available in IJSEM Online). All strains grew at $15-28{ }^{\circ} \mathrm{C}$ but not at 4 or $40{ }^{\circ} \mathrm{C}$. They required $\mathrm{NaCl}$ for growth and thrived in media containing $0.9-6 \%(\mathrm{w} / \mathrm{v}) \mathrm{NaCl}$, but not with more than $8 \%$ total salinity. The strains grew well on several sole carbon and energy sources. Detailed information on phenotypic properties is displayed in Supplementary Table S1 and in the species description.

Isolation of genomic DNA was done according to Pitcher et al. (1989). Reference strains included the type strains of E. norvegicus, E. coralii, V. calviensis, G. hollisae and Vibrio cholerae (Table 1). Amplification and partial sequencing of genes coding for $16 \mathrm{~S}$ rRNA, $r e c A$ and $r p o D$ were performed as described previously by Macián et al. (2001b), Thompson et al. (2005a) and Le Roux et al. (2005), respectively. Multiple sequence alignments were obtained using CLUSTAL_X (Thompson et al., 1997). The lengths of the sequences used for further analysis were $786 \mathrm{nt}(\operatorname{rec} A)$, $876 \mathrm{nt}(r p o D), 1348 \mathrm{nt}$ (16S rRNA) and $3010 \mathrm{nt}$ (concatenated sequences). Phylogenetic analysis was performed using the program PAUP* version 4.0b10 (Swofford, 2002). Neighbour-joining (NJ; with Kimura's two-parameter

Table 1. Strains included in this study

Accession numbers given in italics were retrieved from public databases for the same strain or known equivalents. NA, No sequence available.

\begin{tabular}{|c|c|c|c|c|}
\hline \multirow[t]{2}{*}{ Strain } & \multirow[t]{2}{*}{ Origin } & \multicolumn{3}{|c|}{ GenBank accession number } \\
\hline & & $16 S$ rRNA & recA & rpoD \\
\hline \multicolumn{5}{|l|}{ E. norvegicus } \\
\hline CECT $7288^{\mathrm{T}}$ & Scophthalmus maximus larvae, gut, Norway (1997) & AJ316208 & AM942075 & AM942062 \\
\hline LMG 19840 & As above & AJ316207 & AJ842349 & NA \\
\hline LMG 19842 & As above & AJ437193 & AJ842350 & NA \\
\hline CAIM $912^{\mathrm{T}}$ & Bleached Merulina ampliata extract, Australia (2002) & AJ842343 & AM942063 & AM942051 \\
\hline $8 / 13$ & Dentex dentex, head kidney, Castellón, Spain (1997) & AM942725 & AM942064 & AM942052 \\
\hline $9 / 1 \mathrm{a}$ & As above & AM942726 & AM942065 & AM942053 \\
\hline $9 / 1 c$ & As above & AM942727 & AM942067 & AM942054 \\
\hline $9 / 2 \mathrm{a}$ & As above & AM942728 & AM942066 & AM942055 \\
\hline \multicolumn{5}{|l|}{ E. nigricans sp. nov. } \\
\hline DAl $1-1-5^{\mathrm{T}}$ & Sparus aurata head kidney, Alcanar, Spain (2000) & AM942722 & AM942072 & AM942048 \\
\hline DAl 1-1-4 & As above & AM942723 & AM942073 & AM942049 \\
\hline $8 / 6 b$ & Dentex dentex, head kidney, Castellón, Spain (1997) & AM942724 & AM942074 & AM942050 \\
\hline G. hollisae CECT $5069^{\mathrm{T}}$ & Human faeces, Annapolis, MD, USA & AJ514909 & AM942076 & AM942061 \\
\hline V. cholerae CECT $514^{\mathrm{T}}$ & Human faeces & X76337 & AM942078 & AM942060 \\
\hline
\end{tabular}


correction), maximum-parsimony (MP; heuristic search option) and maximum-likelihood (ML) analyses were done for each of the genes and the concatenated sequence. For ML, the optimal models of nucleotide substitution were estimated through the program MODELTEST 3.7 (Posada \& Crandall, 1998; Posada \& Buckley, 2004) using the Akaike information criterion (AIC). All bootstrap analyses were performed using 1000 replications. The different trees obtained with NJ are shown in Fig. 1. The trees obtained by using the MP and ML algorithms displayed the same topology as those obtained with NJ for each set of sequences in most cases (Supplementary Figs S2 and S3). Table 2 shows the percentages of pairwise sequence similarity within and between species.

Cellular fatty acid analyses of strains DAl 1-1-5 $5^{\mathrm{T}}, 8 / 6 \mathrm{~b}$ and V. calviensis DSM $14347^{\mathrm{T}}$ were performed by GLC at the DSMZ using a method described previously (Kämpfer \& Kroppenstedt, 1996). Cells were harvested from cultures grown on MA plates incubated at $26{ }^{\circ} \mathrm{C}$ for $24 \mathrm{~h}$. Results showed that strains DAl $1-1-5^{\mathrm{T}}$ and $8 / 6 \mathrm{~b}$ exhibited very similar profiles, whereas their close relatives differed mainly in the relative amounts of fatty acids common to all and in the presence or absence of some minor fatty acids (Supplementary Table S2). DNA G+C content was determined by HPLC at the DSMZ according to Mesbah et al. (1989).

DNA-DNA hybridization experiments were done by the hydroxyapatite method using microtitre plates as described by Ziemke et al. (1998) with a hybridization temperature $\left(T_{\mathrm{m}}\right)$ of $50{ }^{\circ} \mathrm{C}$. DNA from strain DAl $1-1-5^{\mathrm{T}}$ was labelled and assayed against DNA from the remaining wild strains and E. coralii CAIM $912^{\mathrm{T}}$. DNA from strain $8 / 13$ was assayed against DNA from E. coralii CAIM $912^{\mathrm{T}}$ and most of the other isolates (Supplementary Table S3).

Considering all the data obtained, it can be concluded that eight of the fish isolates belong to the species E. coralii, as they form a tight, independent clade with the type strain, $E$. coralii CAIM $912^{\mathrm{T}}$, in sequence analyses performed with the three genes employed in this study, $16 \mathrm{~S}$ rRNA, $r p o D$ and recA (Fig. 1 and Supplementary Figs S2 and S3). The maximal percentages of sequence difference within the species were $0.9 \%$ ( $16 \mathrm{~S}$ rRNA), $2.1 \%$ ( $r e c A), 1.0 \%$ ( $r p o D)$ and $1.2 \%$ (concatenated sequences), which are considerably lower than the minimal interspecies percentage of sequence difference recorded for each of the datasets (2.4, 11.7, 12.4 and $7.7 \%$, respectively; Table 2). The strains in the clade shared more than $70 \%$ DNA-DNA relatedness in hybridization experiments with strain $8 / 13$, which had $97.6 \%$ reassociation to the DNA of E. coralii CAIM $912^{\mathrm{T}}$ (Supplementary Table S3). Some phenotypic features of these novel E. coralii strains do not fit the original species description: arginine dihydrolase was variable (six of eight strains positive) and indole production was positive in all strains (including the type strain CAIM $912^{\mathrm{T}}$, reported as negative in the original description). Additional information on phenotypic characteristics of the strains is given below: they grew in TCBS agar as green colonies, from 0.9 to $7 \%$ total salinity on MA (growth was variable at $8 \%$ and negative at $9 \%$ or more), they grew at $15-37{ }^{\circ} \mathrm{C}$ but not at 4 or $40{ }^{\circ} \mathrm{C}$, the indole reaction in $\mathrm{MB}$ was strongly positive, Thornley's arginine dihydrolase test was negative in short incubations (up to $48 \mathrm{~h}$ ) but turned positive for six of the eight strains after prolonged incubation, lysine decarboxylase, ornithine decarboxylase and the Voges-Proskauer reaction were negative. They reduced nitrate to nitrite. None of the strains was able to hydrolyse casein, gelatin, starch, alginate or lecithin; the only extracellular hydrolytic activities displayed were against Tween 80 and DNA (weak). Nutritional screening on basal medium agar plus sole carbon sources revealed a narrow range of compounds that sustained growth (Supplementary Table S1). This is also the first report of E. coralii strains isolated from fish, since the type strain was isolated from a diseased coral sample and to the best of our knowledge was the only known strain.

The remaining three fish isolates (DAl 1-1-4, DAl 1-1-5 $5^{\mathrm{T}}$ and $8 / 6 \mathrm{~b}$ ) constitute a well-defined clade whose sister group is E. coralii in all phylogenetic reconstructions done with $r p o D$ and the concatenated sequences. The branching order in these six trees is also supported by high bootstrap values. The three 16S rRNA gene trees and the recA MP reconstruction show a somewhat different topology, since the clade formed by the three fish isolates merges with the pair E. norvegicus $-V$. calviensis, whereas, in the recA NJ and ML trees, the clade joins a group that includes E. coralii, E. norvegicus and V. calviensis (Fig. 1 and Supplementary Figs S2 and S3). These two topologies are generally less well supported by bootstrap analysis. In any case, and even if the relative order of evolution can not be completely ascertained, it is clear that the three fish isolates (DAl 1-1-4, DAl $1-1-5^{\mathrm{T}}$ and $8 / 6 \mathrm{~b}$ ) and $V$. calviensis are members of genus Enterovibrio. In all the trees obtained, G. hollisae occupies a peripheral position. In terms of sequence similarity, G. hollisae has, on average, a larger number of differences from Enterovibrio species than the Enterovibrio sequences display among themselves (Table 2).

DNA-DNA hybridization assays (Supplementary Table S3) confirm that the three fish isolates (DAl 1-1-4, DAl 1-1-5 and $8 / 6 \mathrm{~b}$ ) constitute a genomic species. All other strains, including CAIM $912^{\mathrm{T}}$, yielded values of $36-63 \%$, which are below the threshold for genospecies definition (Wayne et al., 1987) and in the range of close congeneric species (for example, Vibrio parahaemolyticus and Vibrio harveyi show 47-59\% reassociation; Baumann \& Baumann, 1981). The three fish isolates (DAl 1-1-4, DAl 1-1-5 ${ }^{\mathrm{T}}$ and $8 / 6 \mathrm{~b}$ ) could also be differentiated phenotypically from other Enterovibrio species (Table 3 and Supplementary Table S1). We therefore propose to recognize these three strains as members of a novel species, Enterovibrio nigricans sp. nov.

In the present work, the position of the type strain of $V$. calviensis as a member of the monophyletic group of 


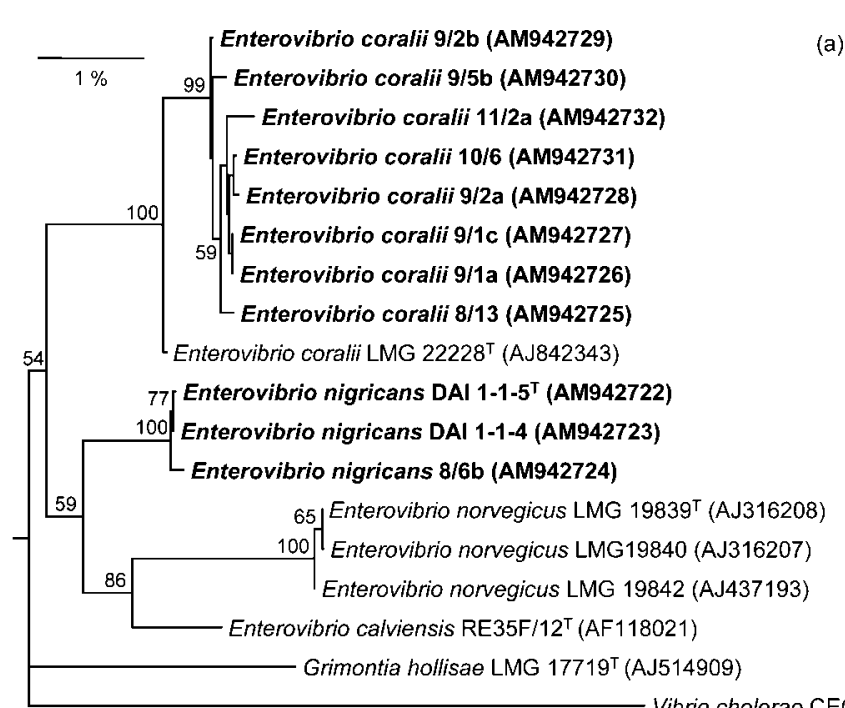

Vibrio cholerae CECT 514 (X76337)

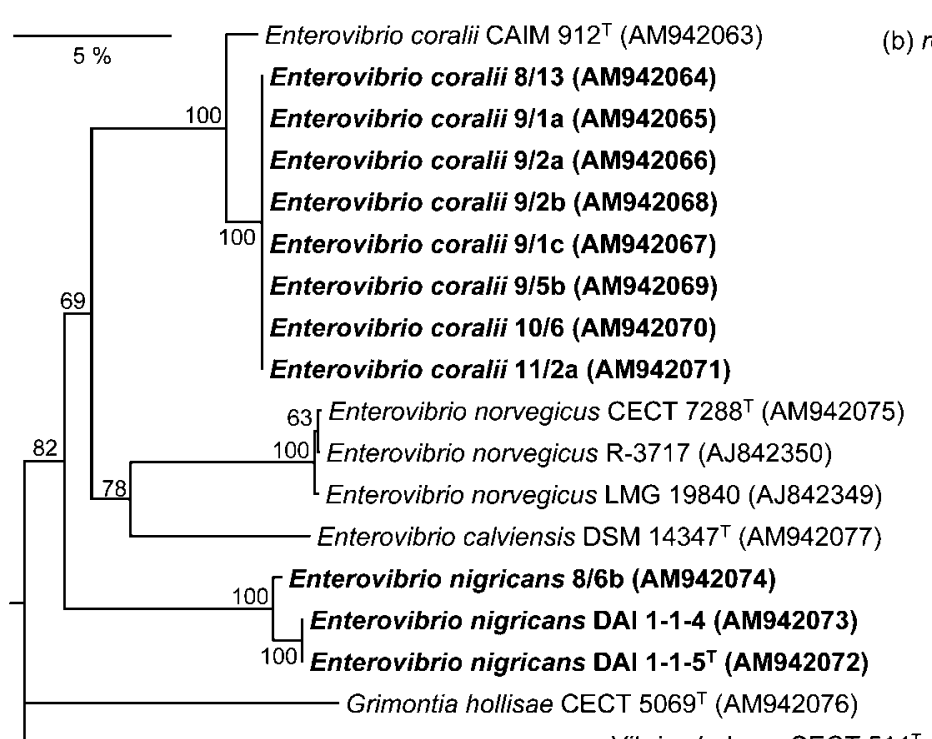

Vibrio cholerae CECT $514^{\top}$ (AM942078)

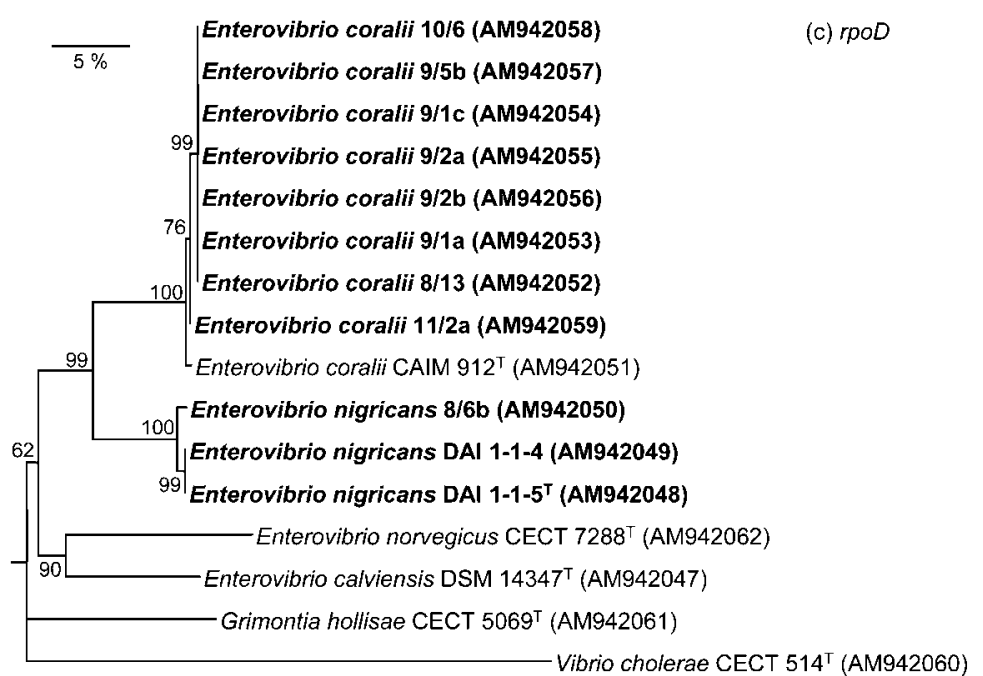

\section{Enterovibrio coralii 8/13}

Enterovibrio coralii 9/2a

Enterovibrio coralii 9/2b

100 Enterovibrio coralii 10/6

Enterovibrio coralii 9/1a

100 Enterovibrio coralii 9/1c

100 Enterovibrio coralii 9/5b

Enterovibrio coralii 11/2a

Enterovibrio coralii CAIM $912^{\top}$

100 Enterovibrio nigricans DAI 1-1-5

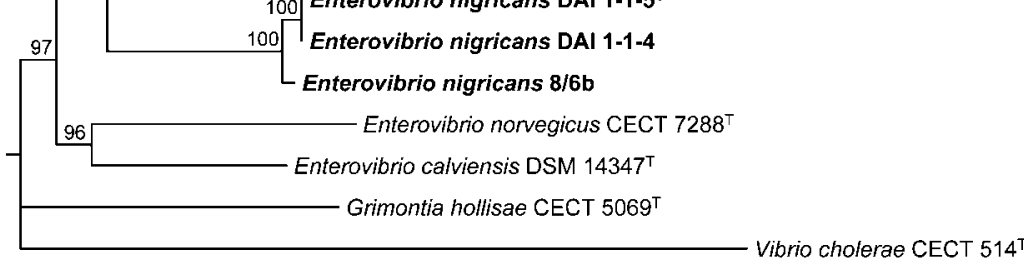

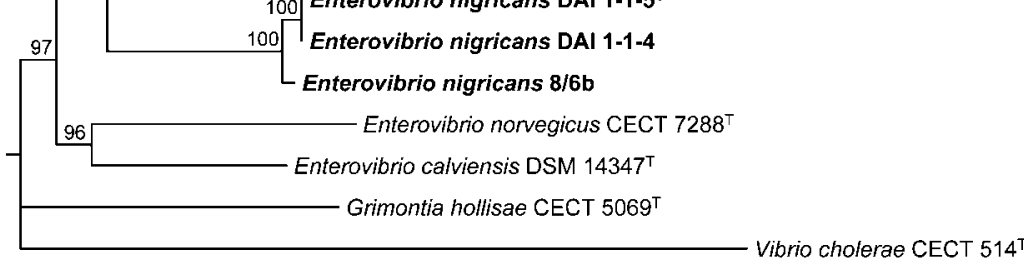

Fig. 1. Neighbour-joining trees based on partial $16 \mathrm{~S} \mathrm{rRNA}(\mathrm{a}), \mathrm{rec} A(\mathrm{~b})$ and $r p o D$ (c) gene sequences of $E$. nigricans sp. nov., $E$. calviensis comb. nov., E. norvegicus, $E$. coralii, G. hollisae and V. cholerae and the concatenated dataset (d). Bars, 1 (a) or 5 (b-d) estimated substitutions per 100 base positions (note that the scale is not the same for all trees). Bootstrap values greater than $50 \%$ confidence are shown at branching points (as percentages of 1000 resamplings). Sequence accession numbers are given in parentheses. 
Table 2. Relatedness between members of the genera Enterovibrio and Grimontia as percentages of $16 \mathrm{~S}$ rRNA, recA, rpoD and concatenated sequence similarity

Intraspecific variability (in bold) applies to E. nigricans sp. nov. (three strains), E. coralii (nine strains) and E. norvegicus (three strains, for $16 \mathrm{~S}$ rRNA and recA only).

\begin{tabular}{|c|c|c|c|c|c|}
\hline Species & 1 & 2 & 3 & 4 & 5 \\
\hline \multicolumn{6}{|l|}{ 16S rRNA } \\
\hline 1. E. nigricans & 99.9-100 & & & & \\
\hline 2. E. coralii & $96.7-97.6$ & 99.1-100 & & & \\
\hline 3. E. norvegicus & $96.8-97.2$ & $95.2-96.3$ & 100 & & \\
\hline 4. E. calviensis & $97.5-97.6$ & $96.5-97.2$ & $97.3-97.4$ & - & \\
\hline 5. G. hollisae & 96.0 & $95.1-96.1$ & $95.1-95.8$ & 95.1 & - \\
\hline \multicolumn{6}{|l|}{$\operatorname{rec} A$} \\
\hline 1. E. nigricans & 98.8-100 & & & & \\
\hline 2. E. coralii & $86.0-87.0$ & 97.9-100 & & & \\
\hline 3. E. norvegicus & $83.6-84.2$ & $87.2-88.0$ & 99.6-99.9 & & \\
\hline 4. E. calviensis & $84.9-84.7$ & 87.4 & $88.0-88.3$ & - & \\
\hline \multicolumn{6}{|l|}{ rpoD } \\
\hline 1. E. nigricans & 98.9-100 & & & & \\
\hline 2. E. coralii & $87.0-87.6$ & 99.0-100 & & & \\
\hline 3. E. norvegicus & 76.6 & $75.1-76.3$ & - & & \\
\hline 4. E. calviensis & $80.0-80.6$ & $78.5-80.4$ & 78.9 & - & \\
\hline 5. G. hollisae & $74.7-74.9$ & $76.7-78.1$ & 73.8 & 76.1 & - \\
\hline \multicolumn{6}{|l|}{ Concatenated } \\
\hline 1. E. nigricans & 99.3-100 & & & & \\
\hline 2. E. coralii & $91.8-92.3$ & 98.8-100 & & & \\
\hline 3. E. norvegicus & $88.8-89.0$ & $88.6-89.2$ & - & & \\
\hline 4. E. calviensis & $90.1-90.3$ & $90.0-90.6$ & 90.8 & - & \\
\hline 5. G. hollisae & $87.3-87.7$ & $87.6-88.1$ & 86.7 & 87.2 & - \\
\hline
\end{tabular}

Enterovibrio is clear in all analyses (individual genes and concatenated sequences) and with all algorithms used (NJ, $\mathrm{MP}, \mathrm{ML})$. In fact, $V$. calviensis relates directly to the type species of the genus, showing a position always closer to $E$. norvegicus than to $E$. coralii or $E$. nigricans sp. nov. Sequence similarity values for each of the sequence datasets confirm that $V$. calviensis should be considered a member of the genus Enterovibrio (Supplementary Table S2). Moreover, the results of the phenotypic characterization of the type strain done in the present study (see Supplementary Table S1) show some discrepancies with the original description of $V$. calviensis (such as the inability to grow with glucose and $N$-acetyl D-glucosamine) and altogether support the transfer of $V$. calviensis to the

Table 3. Differentiation between E. nigricans sp. nov. and other Enterovibrio species

Data were obtained in this study for the following strains: E. nigricans sp. nov. 8/6b, DAl 1-1-4 and DAl 1-1-5 ${ }^{\mathrm{T}}$, E. coralii 8/13, 9/1a, 9/1c, 9/2a, 9/2b, 9/5b, 10/6, 11/2a and CAIM $912^{\mathrm{T}}$, E. norvegicus CECT $7288^{\mathrm{T}}$ and $E$. calviensis comb. nov. DSM $14347^{\mathrm{T}}$. The response of individual strains to a large set of nutritional tests can be found in Supplementary Table S1. v, Variable between strains.

\begin{tabular}{|lcccc|}
\hline Characteristic & E. nigricans & E. coralii & E. norvegicus & E. calviensis \\
\hline Pigment production & $\mathrm{V}$ & - & - & - \\
Indole production & - & + & + & - \\
Growth on/at: & - & - & + & + \\
$4{ }^{\circ} \mathrm{C}$ & - & + & + & - \\
$37{ }^{\circ} \mathrm{C}$ & - & + & + & + \\
$7 \%$ salinity & - & + & + & + \\
L-Alanine & - & + & + & + \\
D-Mannitol & & & & \\
\hline
\end{tabular}


genus Enterovibrio and an the emended description of the genus. Therefore, we also propose the new combination Enterovibrio calviensis comb. nov. and an emended description of the genus.

\section{Description of Enterovibrio nigricans sp. nov.}

Enterovibrio nigricans (ni'gri.cans. L. part. adj. nigricans blackish).

Gram-negative, motile rods or coccobacilli. Cells are 1.0 $1.5 \mu \mathrm{m}$ long and $0.4-0.7 \mu \mathrm{m}$ wide. Chemo-organotrophic and facultatively anaerobic, able to ferment glucose without gas production under anaerobic conditions. Oxidase-positive. Some strains reduce nitrate to nitrite, but not to $\mathrm{N}_{2}$. Able to grow on seawater-based media such as MA, on which some strains produce a black/deepbrown, slightly diffusible pigment. Colonies are round, with entire margins and a bright surface. They also grow on TSA supplemented with $1 \% \mathrm{NaCl}$. They do not swarm or luminesce. Growth on TCBS agar is scarce and slow, producing green (non-sucrose-fermenting) colonies. Growth is observed at $15-28{ }^{\circ} \mathrm{C}$ but not at 4 or $37{ }^{\circ} \mathrm{C}$. Requires $\mathrm{NaCl}$ for growth. Media containing 0.9-6.0\% total salinity sustain good growth; no growth is observed at 0.4 or $7 \%$ or more salinity. In $\mathrm{O} / \mathrm{F}$ medium, acid is produced under anaerobic conditions from D-mannose, sucrose (weakly) and melibiose (weakly and only strain 8/ $6 \mathrm{~b})$. The following carbohydrates are not fermented: Dribose, D-xylose, L-arabinose, D-fructose, D-galactose, trehalose, L-rhamnose, maltose, cellobiose, lactose, amygdalin, salicin, D-mannitol, D-sorbitol and myo-inositol. Under aerobic conditions, strain 8/6b, but not DAl 1-1-4 or DAl 1-1-5 ${ }^{\mathrm{T}}$, produces acid from D-fructose, D-galactose, lactose, melibiose, D-mannitol and D-sorbitol. None of the known strains is able to hydrolyse casein, gelatin, starch, alginate or lecithin. Tween 80 and DNA are degraded, the latter weakly. Thornley's arginine dihydrolase test is variable. Lysine decarboxylase, ornithine decarboxylase, indole and Voges-Proskauer tests are negative. Carbon sources that support growth are D-glucose, D-mannose, $\mathrm{N}$ acetyl D-glucosamine, D-gluconate and L-glutamate. The use of D-ribose, D-fructose, fumarate, acetate, lactate and glycerol is variable among strains. No growth is observed on L-arabinose, D-xylose, trehalose, D-galactose, L-rhamnose, maltose, cellobiose, sucrose, lactose, melibiose, salicin, amygdalin, D-mannitol, D-sorbitol, myo-inositol, D-glycerate, D-saccharate, D-glucuronate, D-galacturonate, pyruvate, propionate, butyrate, citrate, trans-aconitate, 2 oxoglutarate, succinate, malate, 3-hydroxybutyrate, glycine, L-leucine, L-serine, L-threonine, L-alanine, L-arginine, L-tyrosine, L-ornithine, L-citrulline, L-aspartate, L-histidine, L-lysine, L-sarcosine or putrescine. The major cellular fatty acids are $16: 1 \omega 7 c$ and/or iso-15:0 $2-\mathrm{OH}(43-50 \%$ in known strains), 16:0 (18-19\%) and $18: 1 \omega 7 c(11-15 \%)$. Minor amounts $(1-5 \%)$ of the following fatty acids are also detectable: $12: 0,12: 03-\mathrm{OH}, 14: 0,14: 03-\mathrm{OH} /$ iso$16: 1 \mathrm{I}$, iso- $16: 0$ and $16: 1 \omega 9 c$.
The type strain is DAl $1-1-5^{\mathrm{T}}\left(=\mathrm{CECT} 7320^{\mathrm{T}}=\mathrm{CAIM}\right.$ $661^{\mathrm{T}}$ ), isolated from the head kidney of Sparus aurata cultured on the Spanish Mediterranean coast. The type strain produces black pigment, is negative for arginine dihydrolase and positive for nitrate reduction and has a DNA G $+\mathrm{C}$ content of $47.9 \mathrm{~mol} \%$.

\section{Description of Enterovibrio calviensis comb. nov.}

Enterovibrio calviensis (cal.vi.en'sis. N.L. masc. adj. calviensis pertaining to the Bay of Calvi, Corsica, from where the type strain was isolated).

Basonym: Vibrio calviensis Denner et al. 2002.

The description is the same as given for Vibrio calviensis by Denner et al. (2002), with the following modifications: Dglucose, D-fructose and $N$-acetyl D-glucosamine, but not Dmannose, are used as sole carbon and energy sources for growth. The type strain designated in the original publication is RE35F/12 $=$ DSM $14347^{\mathrm{T}}=\mathrm{CIP} 107077^{\mathrm{T}}$. However, in the abstract, it is cited twice as RE35/F12 (Denner et al., 2002). According to StrainInfo (http:// www.straininfo.net), other equivalences of the type strain are ATCC BAA- $606^{\mathrm{T}}$ and CCUG $48319 \mathrm{~B}^{\mathrm{T}}$. As part of this study, the type strain has been also deposited at the Spanish Type Culture Collection as CECT $7414^{\mathrm{T}}$.

\section{Emended description of the genus Enterovibrio Thompson et al. 2002}

The description is the same as that provided by Thompson et al. (2002) with the following modifications: arginine dihydrolase activity, indole production, nitrate reduction and susceptibility to the vibriostatic agent $\mathrm{O} / 129$ may be variable among species. The main fatty acids are $16: 1 \omega 7 \mathrm{cl}$ iso-15:0 2-OH (32-50\% in known strains), 16:0 (15$21 \%)$ and $18: 1 \omega 7 c(11-23 \%)$. Other fatty acids detected (up to $5 \%$ ) in all species, even under different growth conditions, are $16: 1 \omega 9 c, 18: 1 \omega 9 c, 12: 0,14: 0,14: 03$ $\mathrm{OH} /$ iso- $16: 1 \mathrm{I}, 12: 03-\mathrm{OH}, 18: 0$ and iso- $16: 0$. The $\mathrm{G}+\mathrm{C}$ content of the DNA is $47-50 \mathrm{~mol} \%$.

\section{Acknowledgements}

This work has been supported by project CGL2005-02292 of the Spanish Ministerio de Educación y Ciencia to M.J.P. D. R. A. and M.C.M. have contracts with the University of Valencia under the 'Ramón y Cajal' and PTA programs, respectively (Ministerio de Educación y Ciencia, Spain). J.P. acknowledges a postgraduate fellowship from the Ministerio de Educación y Ciencia, Spain.

\section{References}

Baumann, P. \& Baumann, L. (1981). The marine gram-negative eubacteria: genera Photobacterium, Beneckea, Alteromonas, Pseudomonas and Alcaligenes. In The Prokaryotes, vol. I, pp. 13021331. Edited by M. P. Starr, H. Stolp, H. G. Trüper, A. Balows \& H. Schlegel. Berlin \& Heidelberg: Springer. 
Company, R., Sitjà-Bobadilla, A., Pujalte, M. J., Garay, E., ÁlvarezPellitero, P. \& Pérez-Sánchez, J. (1999). Bacterial and parasitic pathogens in cultured common dentex (Dentex dentex L.).J Fish Dis 22, 299-310.

Denner, E. B. M., Vybiral, D., Fischer, U. R., Velimirov, B. \& Busse, H.-J. (2002). Vibrio calviensis sp. nov., a halophilic, facultatively oligotrophic $0.2 \mu \mathrm{m}$-filterable marine bacterium. Int $J$ Syst Evol Microbiol 52, 549-553.

Kämpfer, P. \& Kroppenstedt, R. M. (1996). Numerical analysis of fatty acid patterns of coryneform bacteria and related taxa. Can J Microbiol 42, 989-1005.

Le Roux, F., Goubet, A., Thompson, F. L., Faury, N., Gay, M., Swings, J. \& Saulnier, D. (2005). Vibrio gigantis sp. nov., isolated from the haemolymph of cultured oysters (Crassostrea gigas). Int $J$ Syst Evol Microbiol 55, 2251-2255.

Macián, M. C., Ludwig, W., Schleifer, K. H., Garay, E., Aznar, R., Grimont, P. A. D. \& Pujalte, M. J. (2001a). Vibrio lentus sp. nov., isolated from Mediterranean oysters. Int J Syst Evol Microbiol 51, 1449-1456.

Macián, M. C., Ludwig, W., Schleifer, K. H., Garay, E. \& Pujalte, M. J. (2001b). Thalassomonas viridans gen. nov., sp. nov., a novel marine $\gamma$ proteobacterium. Int J Syst Evol Microbiol 51, 1283-1289.

Mesbah, M., Premachandran, U. \& Whitman, W. B. (1989). Precise measurement of the $\mathrm{G}+\mathrm{C}$ content of deoxyribonucleic acid by highperformance liquid chromatography. Int J Syst Bacteriol 39, 159-167.

Pitcher, D. G., Saunders, N. A. \& Owen, R. J. (1989). Rapid extraction of bacterial genomic DNA with guanidium thiocyanate. Lett Appl Microbiol 8, 151-156.

Posada, D. \& Buckley, T. R. (2004). Model selection and model averaging in phylogenetics: advantages of the Akaike information criterion and Bayesian approaches over likelihood ratio tests. Syst Biol 53, 793-808.

Posada, D. \& Crandall, K. A. (1998). Modeltest: testing the model of DNA substitution. Bioinformatics 14, 817-818.

Pujalte, M. J., Sitjà-Bobadilla, A., Álvarez-Pellitero, P. \& Garay, E. (2003). Carriage of potentially fish-pathogenic bacteria in Sparus aurata cultured in Mediterranean fish farms. Dis Aquat Organ 54, 119-126.

Sawabe, T., Kita-Tsukamoto, K. \& Thompson, F. L. (2007). Inferring the evolutionary history of vibrios by means of multilocus sequence analysis. J Bacteriol 189, 7932-7936.

Swofford, D. L. (2002). PAUP*: Phylogenetic analysis using parsimony (*and other methods), version 4. Sunderland, MA: Sinauer Associates.

Thompson, J. D., Gibson, T. J., Plewniak, F., Jeanmougin, F. \& Higgins, D. G. (1997). The CLUSTAL_X windows interface: flexible strategies for multiple alignment aided by quality analysis tools. Nucleic Acids Res 25, 4876-4882.

Thompson, F. L., Hoste, B., Thompson, C. C., Goris, J., Gómez-Gil, B., Hys, L., De Vos, P. \& Swings, J. (2002). Enterovibrio norvegicus gen. nov., sp. nov., isolated from the gut of turbot (Scophthalmus maximus) larvae: a new member of the family Vibrionaceae. Int J Syst Evol Microbiol 52, 2015-2022.

Thompson, F. L., Hoste, B., Vandemeulebroecke, K. \& Swings, J. (2003). Reclassification of Vibrio hollisae as Grimontia hollisae gen. nov., comb. nov. Int J Syst Evol Microbiol 53, 1615-1617.

Thompson, F. L., Gevers, D., Thompson, C. C., Dawyndt, P., Naser, S., Hoste, B., Munn, C. \& Swings, J. (2005a). Phylogeny and molecular identification of vibrios on the basis of multilocus sequence analysis. Appl Environ Microbiol 71, 5107-5115.

Thompson, F. L., Thompson, C. C., Naser, S., Hoste, B., Vandemeulebroecke, K., Munn, C., Bourne, D. \& Swings, J. (2005b). Photobacterium rosenbergii sp. nov. and Enterovibrio coralii sp. nov., vibrios associated with coral bleaching. Int J Syst Evol Microbiol 55, 913-917.

Wayne, L. G., Brenner, D. J., Colwell, R. R., Grimont, P. A. D., Kandler, O., Krichevsky, M. I., Moore, L. H., Moore, W. E. C., Murray, R. G. E. \& other authors (1987). International Committee on Systematic Bacteriology. Report of the ad hoc committee on reconciliation of approaches to bacterial systematics. Int J Syst Bacteriol 37, 463-464.

Ziemke, F., Höfle, M. G., Lalucat, J. \& Rosselló-Mora, R. (1998). Reclassification of Shewanella putrefaciens Owen's genomic group II as Shewanella baltica sp. nov. Int J Syst Bacteriol 48, 179-186. 